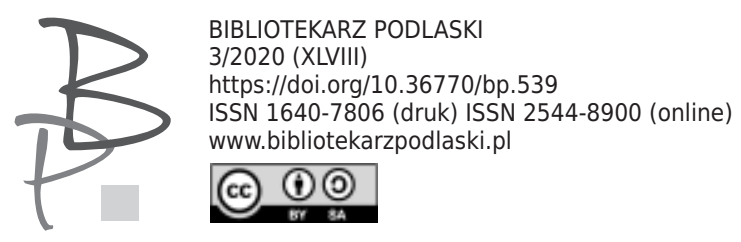

\author{
Jarosław Ławski* \\ Uniwersytet w Białymstoku \\ https://orcid.org/0000-0002-1167-5041
}

\title{
Międzynarodowa Konferencja Naukowa „Polacy w Odessie”, Odessa, 10-11 września 2018 roku. Sprawozdanie
}

\author{
International Scientific Conference "Poles in Odessa", \\ Odessa, 10-11 September 2018. A report
}

Rok 2020 okazał się wyjątkowo pechowy dla życia naukowego nie tylko w Polsce, lecz praktycznie na całym świecie. Za sprawą pandemii koronawirusa odwołano niemalże wszystkie znaczne konferencje naukowe, sympozja, kongresy, wykłady gościnne. Wprawdzie niektóre z sesji przeprowadzono w formule online, na ekranach komputerów, ale ich uczestnicy mieli szansę, by osobiście doświadczyć przejmującej różnicy między żywym doświadczeniem międzyludzkiego spotkania w realnej czasoprzetrzeni kulturowo określonego miejsca a „spotkaniem” zapośredniczonym w ekranowej quasi-realności.

Z tym większą nostalgią i przyjemnością przychodzi mi zdać sprawę z wydarzenia, które odbyło się późnym latem 2018 roku w urzekającej rzeczywistości ukraińskiej Odessy. Dopisała pogoda, nie zakłóciły obrad napięte, zewnętrzne, dookolne warunki historyczne (wojna w Donbasie).

\footnotetext{
Jarosław Ławski - prof. dr hab., kierownik Katedry Badań Filologicznych „Wschód - Zachód" na Wydziale Filologicznym Uniwersytetu w Białymstoku. Autor wielu książek, m.in. Mickiewicz -Mit-Historia. Studia (Białystok 2010); Miłosz: ,,Kroniki” istnienia. Sylwy (Białystok 2014).
} 


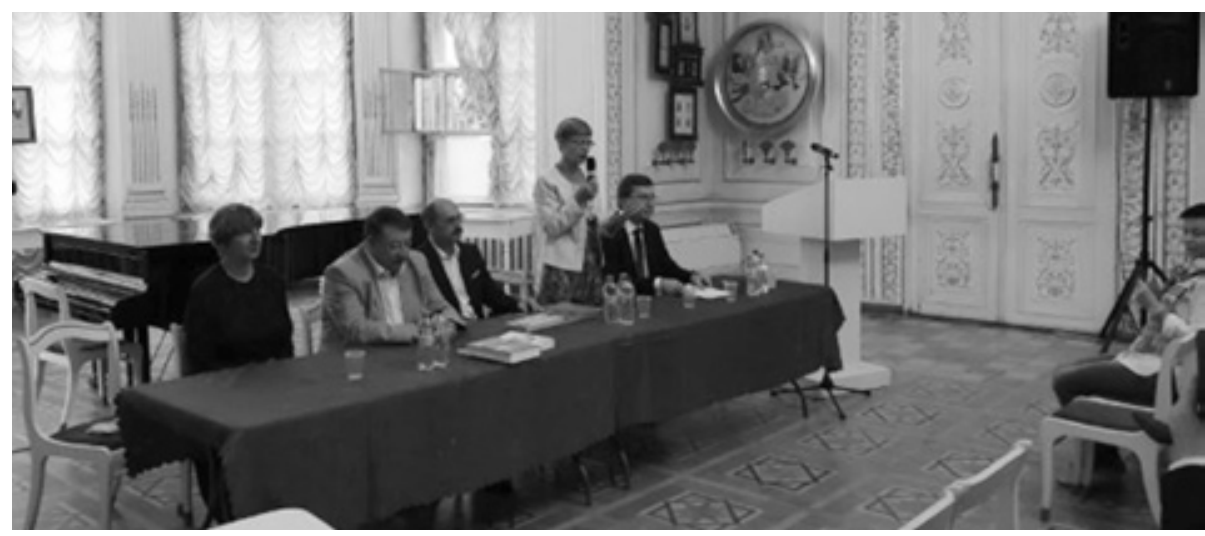

Inauguracja obrad Konferencji w Muzeum Literatury w Odessie.

Od lewej siedzą: Pani Alena Jaworska, śp. prof. Ievgen Chernoivaneko, Prorektor Uniwersytetu w Odessie prof. Wadym M. Chmarski, przemawia prof. Natalia Maliutina, prof. Jarosław Ławski. W pierwszym rzędzie: prof. Anna Janicka

W tej sytuacji możliwe było przeprowadzenie: IV Międzynarodowej Konferencji Naukowej z cyklu „Odessa i Morze Czarne. Polsko-ukraińskie związki kulturowe"1. Odbywająca się w dniach 10-11 września 2018 roku w Odessie w Muzeum Literatury Konferencja poświęcona była zagadnieniu: „Polacy w Odessie i na ukraińskim wybrzeżu Morza Czarnego. Historia - dziedzictwo współistnienie wielokulturowej wspólnoty miasta".

Sesję zorganizowały: Ministerstwo Oświaty i Nauki Ukrainy, Odeski Uniwersytet Państwowy im. Ilji Miecznikowa (Katedra Literatury Ukraińskiej z Wydziału Filologicznego), Katedra Badań Filologicznych „Wschód - Zachód” z Wydziału Filologicznego Uniwersytetu w Białymstoku, Muzeum Literatury w Odessie i Dział Naukowy Książnicy Podlaskiej im. Łukasza Górnickiego. Głównymi organizatorami sesji byli prof. Jarosław Ławski (Uniwersytet w Białymstoku) i prof. Natalia Maliutina (Uniwersytet Odeski i Uniwersytet w Białymstoku). Wkład w organizację imprezy włożyli: śp. prof. Ievgen Chernoivanenko

1 Dotychczas wydano następujące monografie pokonferencyjne: Odessa $w$ literaturach stowiańskich. Studia, red. J. Ławski, N. Maliutina, Białystok - Odessa 2016; Odessa i Morze Czarne jako przestrzeń literacka, red. J. Ławski, N. Maliutina, Białystok - Odessa 2018; Odessa, muzyka, literatura. Ukraińsko-polski transfer kulturowy. Studia, red. N. Maliutina, W. Biegluk-Leś, idea i układ J. Ławski, Białystok - Odessa 2019. 


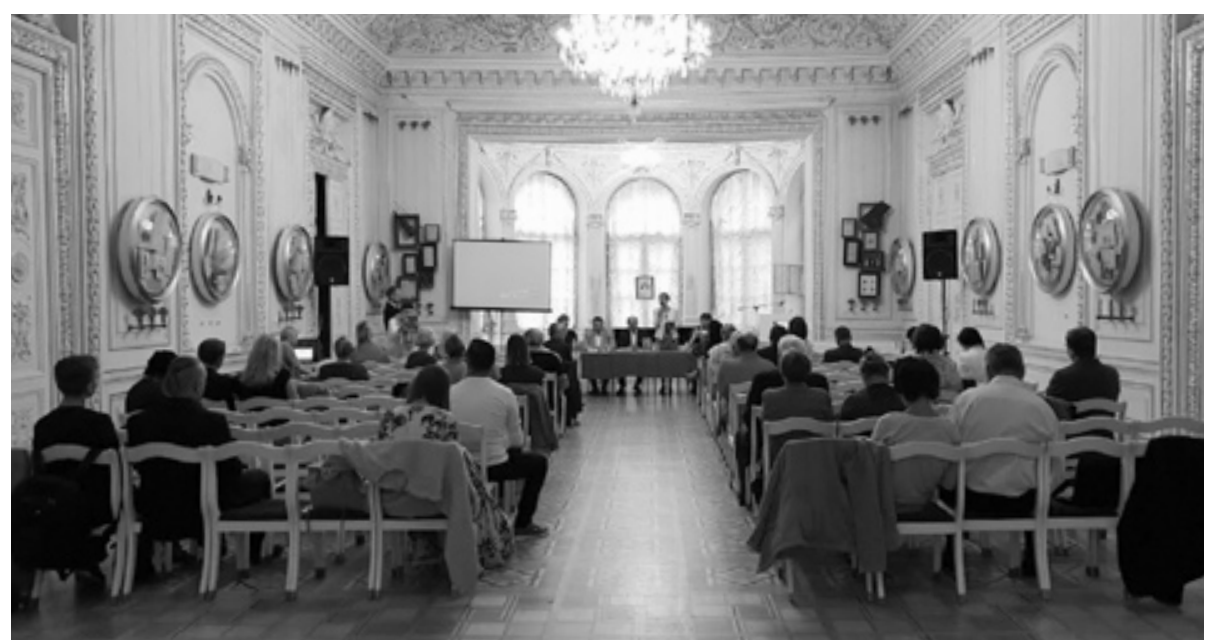

Widok Złotej Sali w Pałacu Księcia Gagarina, siedzibie Muzeum Literatury w Odessie

(Dziekan Wydziału Filologicznego uczelni z Odessy)2, dyrektor Tatiana Liptuga (odeskie Muzeum Literatury) i dyrektor Jolanta Gadek (Książnica Podlaska im. Łukasza Górnickiego). W czasie sesji - w której wzięło udział 40 badaczy z Polski i Ukrainy - podjęto następujące zagadnienia badawcze:

• Dzieje osadnictwa Polaków w Odessie od 1794 roku po współczesność.

- Literatura, sztuka, architektura jako świadectwa obecności Polaków w wielokulturowym i wieloreligijnym świecie odeskim.

- Polacy na ukraińskim wybrzeżu Morza Czarnego: historia, świadectwa, zapisy.

- Mit Odessy w kulturze polskiej.

n Polacy w Odessie oczyma Ukraińców, Rosjan, Francuzów i innych narodowości zamieszkujących miasto.

- Inne narodowości w Odessie i ich relacje wzajemne.

- Morze jako element mitu odeskiego w doświadczeniach społeczności polskiej w Odessie.

• Wkład Polaków w gospodarkę Odessy.

2 Pan Dziekan Ievgen Chernoivanenko (ur. 1952) zmarł 11 stycznia 2021 roku w Odessie. Jest kolejną ofiarą Covid-19. 


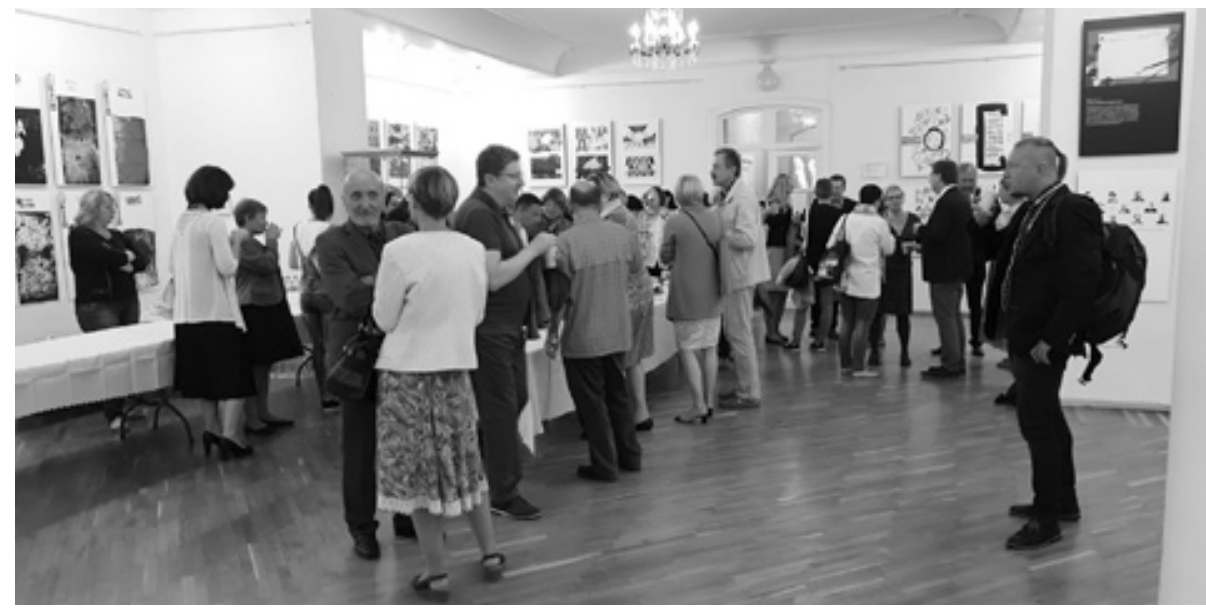

Przyjęcie w galerii Muzeum Literatury, pierwszy od prawej dr Marcin Bajko (UwB, Białystok) w rozmowie z dr. Pawłem Wojciechowskim (UwB, Białystok)

— Polacy w Liceum Richelieu oraz na Uniwersytecie im. Ilji Miecznikowa. - Historia i losy Polaków w Odessie i nad Morzem Czarnym.

- Kościół rzymsko-katolicki i jego dzieje w Odessie.

- Działalność kulturalna i naukowa Polaków we współczesnej Odessie.

- Wielonarodowa Odessa z perspektywy innych kultur europejskich i pozaeuropejskich.

Obrady Konferencji odbywały się w samym sercu Odessy - w Muzeum Literatury. W Złotej Sali Pałacu Gagarina zainaugurowano wystąpieniami śp. prof. Ievgena Chernoivaneki, Dziekana Wydziału Filologicznego Odeskiego Narodowego Uniwersytetu im. Ilji Miecznikowa, prof. Natalii Maliutiny komparatystki pracującej w Odessie i Białymstoku, prof. Jarosława Ławskiego, kierującego Katedrą Badań Filologicznych „Wschód - Zachód” UwB, Pani Jolanty Gadek, dyrektor Książnicy Podlaskiej im. Łukasza Górnickiego i Pani Tatiany Liptugi, dyrektor Muzeum Literatury w Odessie, które już po raz kolejny gościło polsko-ukraińską imprezę naukową.

Rozpoczęte 10 IX o godz. 10.00 obrady kontynuowane były 11 IX od godz. 10.00 do 12.00. Pierwszego, poniedziałkowego dnia obrad po ośmiu referatach sesji plenarnej obradowano w III sekcjach: W orbicie wiecznych powrotów: 


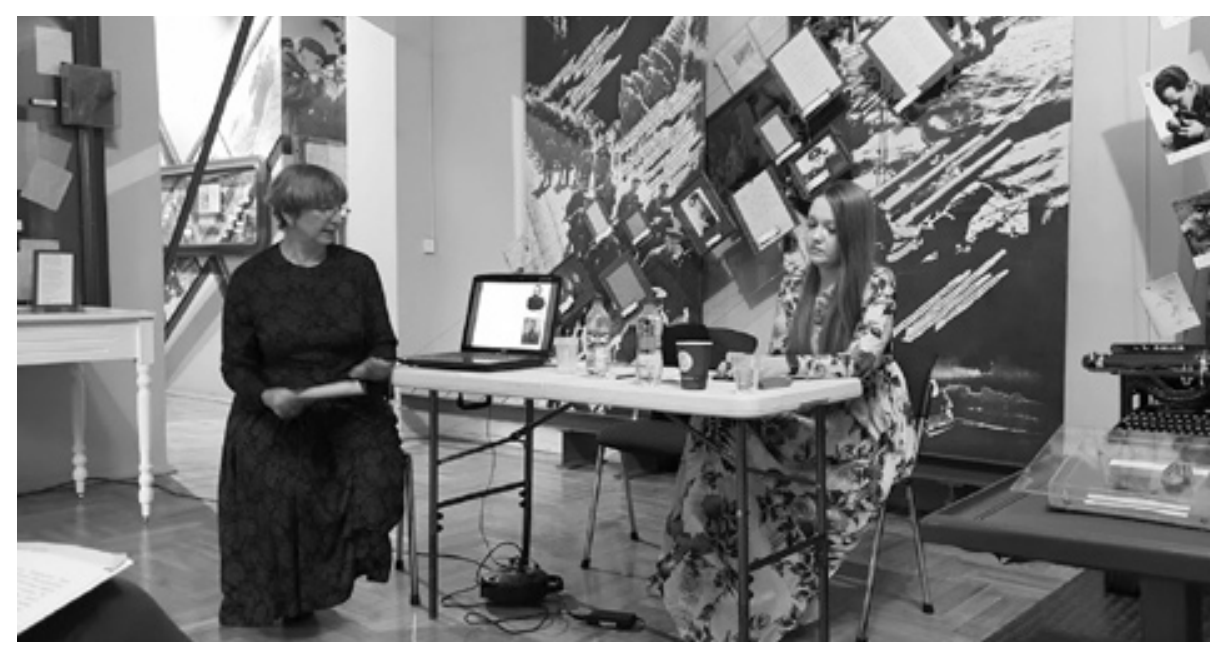

Obrady w sekcji: występuje mgr Alena Jaworska, obrady prowadzi: doc. Irajda Tombułatowa (Odessa)

Adam Mickiewicz oraz polscy pisarze w Odessie XIX - poczatku XX wieku (I); Polska kultura oraz historyczne $i$ współczesne oblicza Odessy: interakcje (II); Odessa oczyma Polaków w literaturze non-fiction (III). We wtorek 11 IX wysłuchano znów aż ośmiu wystąpień (co trochę przeciągnęło obrady), po których rozpoczął się „program kulturalny”: zwiedzanie Odessy, obiad, przejażdżka morska statkiem „Hadżibej”. Należy wydobyć z uznaniem znakomitą atmosferę spotkania: życzliwą, radosną.

Dialogiczny, pokojowy charakter sesji w Odessie o Polakach wydobył w swym wystąpieniu prof. Jerzy Nikitorowicz ${ }^{3}$, były rektor Uniwersytetu w Białymstoku (przebywający w Odessie z Małżonką), skupiając się na Edukacji międzykulturowej w kreowaniu paradygmatu wspótistnienia kultur (10 IX, 10.30). Z kolei prof. Dariusz Rott (UŚ, Katowice) zainaugurował sesję wystąpieniem ,W Wsyscy mi to w Odessie opowiadaja”. Obraz miasta we współczesnym polskim reportażu literackim (szczególnie było to wystąpienie o autokreacjach Ziemowita Szczerka) ${ }^{4}$. Problematyki żydowskiej, jak zawsze,

3 Por. J. Nikitorowicz, Młodzież pogranicza kulturowego Polski, Białorusi, Ukrainy wobec integracji europejskiej, Białystok 2000.

4 Z. Szczerek, Tatuaż z Tryzubem, Czarne 2015. 


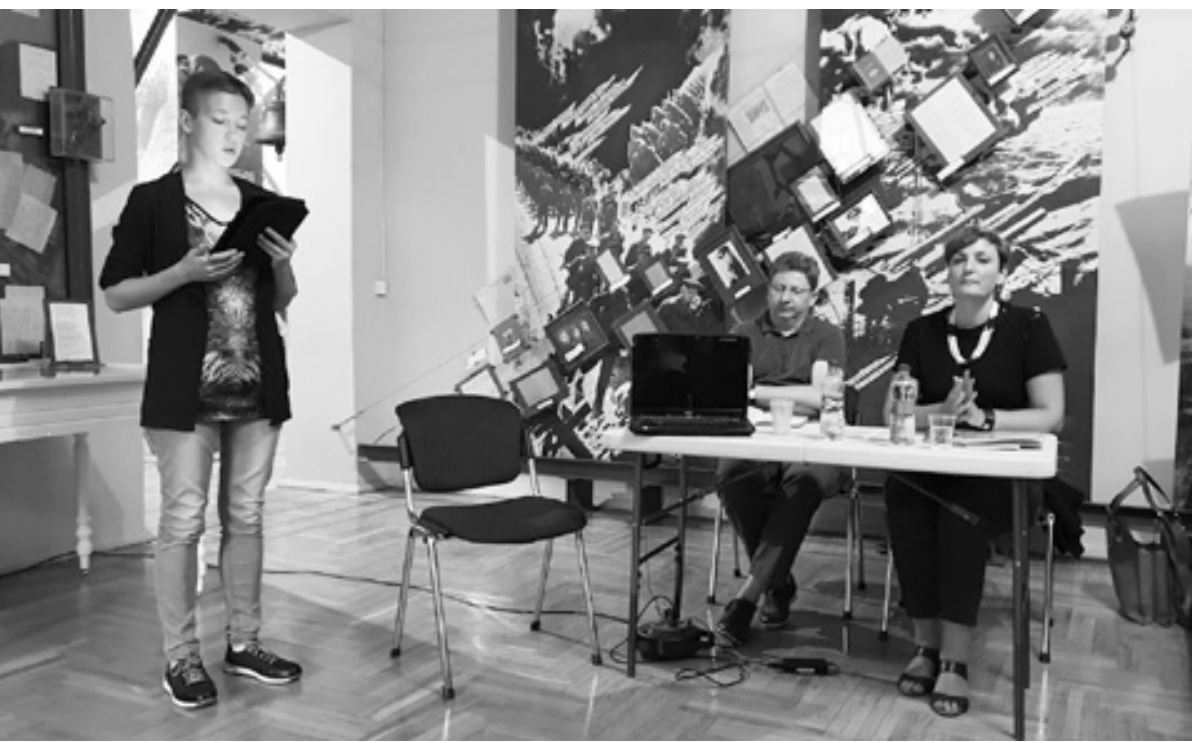

Obrady w sekcji: występuje mgr Irena Szewczenko (UwB, Białystok), obrady prowadzą: doc. dr Iryna Neczytaluk (Odessa) i dr Paweł Wojciechowski (UwB, Białystok)

dotyczyło wystąpienie prof. Lucyny Aleksandrowicz-Pędich (SWPS, Warszawa), amerykanistki, mówiącej na temat: Europejskie ramy tożsamościowe żydowskiego narratora w odeskiej powieści Zeeva Żabotyńskiego „Piatero”.

Intrygująco z kolei dla polskich badaczy romantyzmu zabrzmiały tezy wystąpienia odeskiego rusycysty, doc. dr. Artura Malinowskiego Adam Mickiewicz w Odessie: poeta na zesłaniu, który nie stat się europejskim dandysem (o pragnieniu wolności i sonetach polskiego romantyka). Dr hab. Anna Janicka, prof. UwB przypomniała postać drogiej odeskim Polakom nauczycielki języka polskiego i reanimatorki tutejszego teatru amatorskiego Agnieszki Barbary Cichockiej (1967-2015), przedwcześnie zmarłej entuzjastki Odessy i odesytów, w prelekcji Summa i fragment. O książce Agnieszki Barbary Cichockiej „Odessa inspiracją Polaków”. Ukrainiec pracujący w Poznaniu (UAM), prof. Jarosław Poliszczuk, autor najnowszej, ukraińskiej monografii

5 Książka miała dwa wydania: A. B. Cichocka, Odessa inspiracją Polaków, Odessa 2016. Wydanie 2: Poznań 2017. 


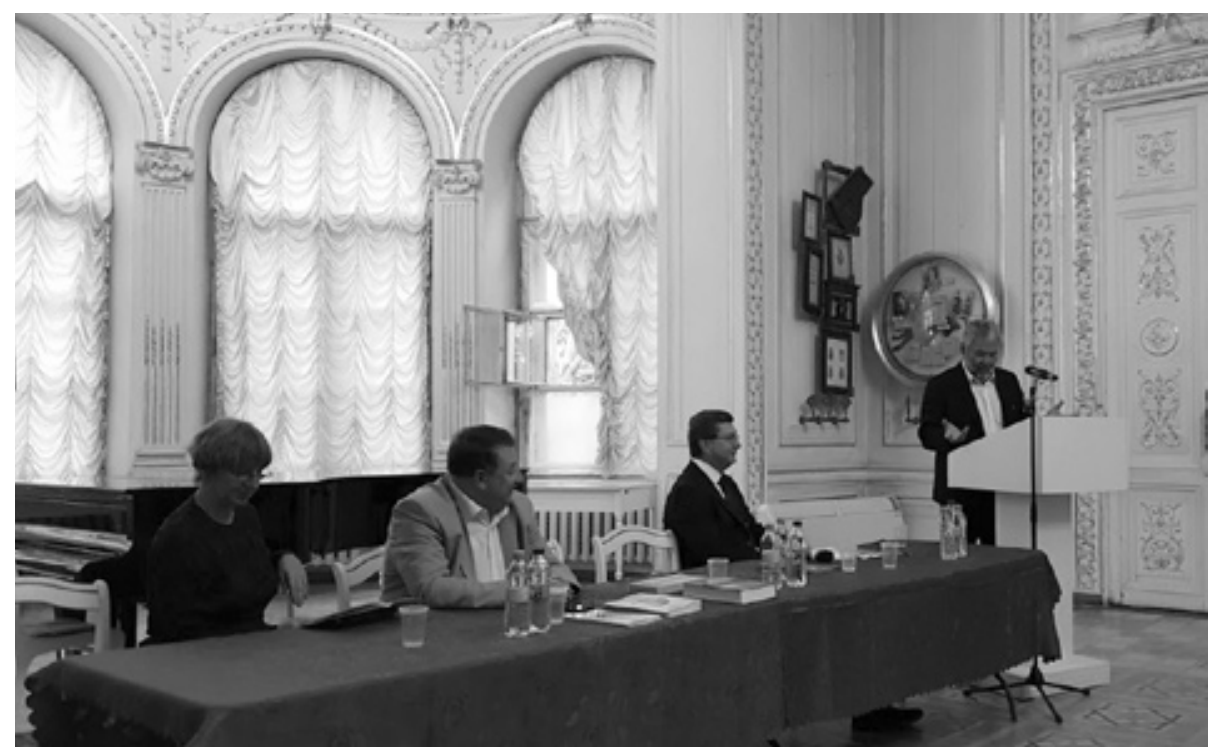

Wystąpienie na obradach plenarnych prof. Jerzego Nikitorowicza (UwB, Białystok)

literackiej, ogólnokulturowej Odessy ${ }^{6}$, podjął temat fundamentalny: Świadomość pogranicza: esej o tożsamości Odessy ${ }^{7}$ Z Z kolei dr hab. Violetta Wróblewska, prof. UMK rozprawiała nader interesująco o Morzu Czarnym $w d u$ mach ukraińskich $w$ przekładzie Jana Mirosława Kasjana.

Nie da się streścić bodaj części wystąpień z bogatego Programu, dostępnego już dziś w bibliotekach polskich ${ }^{8}$. W sesji wzięło udział 40 badaczy, w tym 20 z Polski (z Białegostoku, Katowic, Warszawy, Opola, Rzeszowa, Torunia, Gdańska, Poznania, Krakowa, Wrocławia, Ełku). Godzien odnotowania jest

6 J. Poliszczuk, Frontirna identičnist: Odessa XX stolittia, Duh i litera 2019.

7 Odessa, jej tożsamość budzą coraz większe zainteresowanie w ostatnim czasie. Zob. Ch. King, Odessa. Geniusz i śmierć w mieście snów, przeł. H. Pustuła-Lewicka, Wołowiec 2016; J. Juszkiewicz, Odessa w literaturze polskiej lat 1804-1843. Szkice, Białystok 2020; P. Herlihy, Odessa. A History 1794-1914, Cambridge - Massachusetts 1986; P. Herlihy, Odessa Recollected. The Port and the People, Harvard 2019.

8 Program Konferencji miał charakter dwujęzyczny. Część pierwsza (s. 1-12) był w całości w języku ukraińskim, część druga (s. 13-24) po polsku. Program opr. N. Maliutina i J. Ławski, współpraca red. K. Rutkowski, I. Neczytaluk, skład K. Zaniewski, Białystok 2018. Druk: Wydawnictwo „Prymat”, Mariusz Śliwowski. 
tak liczny udział badaczy ukraińskich występujących z tematami polskimi. Badaczy nade wszystko z Odessy, ale też Równego i Kijowa.

Jak zwykle w takich razach, ważne wydarzenie obserwowane było przez przedstawicieli Związku Polaków na Ukrainie, jego Oddziału im. Adama Mickiewicza w Odessie (którzy przyjęli polską delegację w siedzibie Związku), Konsulat RP w Odessie (który przysłał swych anonimowych przedstawicieli na inaugurację) oraz władze Uniwersytetu Odeskiego (JM Rektor prof. Igor Kowal wysłał swego przedstawiciela na inaugurację). Sesję zgodnie uznano za sukces naukowy i towarzyski9.

Nie byłoby go bez aktywnego wsparcia osób, którym chciałbym złożyć szczególne wyrazy podziękowania: Pani prof. Natalii Maliutiny - spiritus movens polsko-ukraińskich spotkań naukowych, przygotowującej zawsze doskonale grunt pod spotkanie, jego logistykę; jej męża, Pana Iwana Morara, wspomagającego organizacyjnie Konferencję; śp. Pana Dziekana prof. Ievgena Chernoivanenko z Małżonką, którzy byli wielkimi orędownikami tych sesji; Pani dyr. Tatiany Liptugi, godzącej się każdorazowo użyczyć gościny w Muzeum Literatury, i Pani Aleny Jaworskiej, pracownicy Muzeum Literatury, otaczającej badaczy polskich czułą, bezinteresowną opieką; Pana doc. dr. Artura Malinowskiego, czuwającego nad polską delegacją; Pani doc. dr Oksany Szupty-Wiazowskiej z Katedry Ukrainistyki, szczerze wspierającej ideę spotkań, na których nieodmiennie prezentuje ukraiński punkt widzenia na odeskie sprawy; wreszcie Pani doc. dr Iry ny Neczytaluk, badaczki współtworzącej wraz z nami odeskie monografie, i Pani prof. Walentyny Musij, wytrawnej znawczyni rosyjskich dziejów kultury miasta. Wszystkim Państwu winniśmy gorące: dziękujemy!

W 2019 roku badacze obradowali w Białymstoku, gdzie przybyła liczna delegacja uczonych z Odessy ${ }^{10}$. Zaplanowaną na 2020 rok sesję w Odessie o mieście-kobiecie i twórczych kobietach w jego przestrzeni - musieliśmy od-

9 Sesja miał też interesujący aspekt towarzyski, niektórzy jej uczestnicy, jak Kazimierz Bogusz z żoną Moniką, przybyli do Odessy z małżonkami. Inni z kolei uczestnicy przygotowali się szczegółowo do zwiedzania określonych miejsc (jak prof. Lucyna Aleksandrowicz-Pędich wędrująca śladami Żydów odeskich).

10 Zob. T. Szewczenko, Międzynarodowa Konferencja Naukowa „Mit Odessy w kulturze światowej. Teksty - media - wyobrażenia”, Białystok, 24-25 IX 2019 roku. Sprawozdanie, „Bibliotekarz Podlaski" 4/2019. 
wołać z powodu pandemii, przenieść na rok następny. Ironia losu! Pozostają wspomnienia o wydarzeniu tak niepowtarzalnie serdecznym, miłym, jak Konferencja „Polacy w Odessie”, Odessa, 10-11 września 2018 r. Wydanie monografii Polacy w Odessie. Studia interdyscyplinarne zaplanowano na początek roku 2021 w Naukowej Serii Wydawniczej „Colloquia Orientalia Bialostocensia” jako kolejny tom białostockich Studiów odeskich. 